\title{
Percutaneous renal biopsy of native kidneys: efficiency, safety and risk factors associated with major complications
}

Abel Torres Muñoz ${ }^{1}$, Rafael Valdez-Ortiz¹ ${ }^{1}$ Carlos González-Parra ${ }^{1}$, Elvy Espinoza-Dávila², Luis E. Morales-Buenrostro ${ }^{1}$, Ricardo Correa-Rotter ${ }^{1}$

1Department of Nephrology and Mineral Metabolism. Instituto Nacional de Ciencias Médicas y Nutrición Salvador Zubirán, México City, México

${ }^{2}$ Hospital Obrero Nº1 C.N.S., La Paz, Bolivia

Submitted: 9 December 2010

Accepted: 9 June 2011

Arch Med Sci 2011; 7, 5: 823-831

DOI: $10.5114 /$ aoms.2011.25557

Copyright @ 2011 Termedia \& Banach

\section{Abstract}

Introduction: The use of an automated biopsy device and real-time ultrasound (current technology) for percutaneous renal biopsies (PRBs) has improved the likelihood of obtaining adequate tissue for diagnosis and has reduced the complications associated with renal biopsies. Our objective was to evaluate the efficacy and safety of the current PRB procedure and identify possible risk factors for the development of major complications.

Material and methods: We collected all native kidney PRBs performed with current technology in our institute from January 1998 to April 2008. Studied variables were collected from the patient's chart at the time of the biopsy.

Results: We analyzed 623 (96.4\%) of 646 renal biopsies performed with the current automated procedure guided by real-time ultrasound. Although the effectiveness was $97.6 \%$, there were 110 complications. Fourteen $(2.24 \%)$ of these complications were major: 9 cases of renal hematoma, 2 cases with macroscopic hematuria (which needed blood transfusion), 1 case of intestinal perforation (which required exploratory laparotomy), 1 nephrectomy and 1 case of a dissecting hematoma. The logistic regression analysis demonstrated the following risk factors for developing major complications: diastolic blood pressure $\geq 90 \mathrm{mmHg}$, RR $7.6(95 \% \mathrm{Cl} 1.35-43)$; platelet count $\leq 120 \times 10^{3} / \mu \mathrm{l}$; RR 7.0 (95\% Cl 1.9-26.2); and blood urea nitrogen (BUN) $\geq 60 \mathrm{mg} / \mathrm{dl}$, RR 9.27 (95\% Cl 2.8-30.7).

Conclusions: The observed efficacy and safety of the current technique in the present study were similar to observations in previous studies. Diastolic blood pressure $\geq 90 \mathrm{mmHg}$, platelets $\leq 120 \times 10^{3} / \mu \mathrm{l}$ and $\mathrm{BUN} \geq 60 \mathrm{mg} / \mathrm{dl}$ were independent risk factors for the development of major complications following PRB.

Key words: renal biopsy, risk factor, complications, native kidneys.

\section{Introduction}

Percutaneous renal biopsy (PRB) is an essential tool for the practice of nephrology [1]. Although the first description of a technique to perform a PRB was published by Ball in the 1930s [2], it was not until the 1950s that a more practical and efficient technique was clearly described by Ibersen and Brun [3]. With the introduction of the Franklin modified Vim-

\author{
Corresponding author: \\ Ricardo Correa-Rotter MD \\ Departamento de Nefrología \\ y Metabolismo Mineral \\ Instituto Nacional de Ciencias \\ Médicas y Nutrición Salvador \\ Zubirán \\ Vasco de Quiroga \# 15 \\ Colonia Sección XVI. CP \\ 14000 \\ Delegación Tlalpan, México \\ City, México \\ Phone: +52-55-54870900, \\ ext. 2505 \\ Fax: +52-55-56550382 \\ E-mail: \\ correarotter@prodigy.net.mx
}


Silverman needle in 1954 [4], obtaining kidney tissue for proper histological diagnosis improved by $96-98 \%$ [4-6]. Today, most hospitals perform PRBs using realtime ultrasonography and automated percutaneous devices [7-9]. This technique has improved safety and increased the number of procedures that can be performed. In addition to being an initial diagnostic tool, real-time ultrasonography and automated percutaneous devices can also be used to assess the progression of renal injury and response to medical treatment $[10,11]$.

For over a decade, we have performed PRB in our institute using real-time ultrasound and an automatic biopsy device. The first objective of this study was to describe current native kidney PRB indications, main histopathological diagnoses and post-biopsy complications. Although the advantages of the automated technique (compared with the manual technique) have been previously demonstrated [12-15], many centers from developing countries continue to perform PRB with nonautomated devices and, in some cases, without real-time ultrasound guidance. Therefore, we compared our results using automated devices and real-time ultrasound guidance to previously published studies from our center that were not performed with an automatic device and real-time ultrasound guidance [16].

A series of factors has been associated with increased risk of post-biopsy complications [17-19]; these factors include arterial hypertension, amyloidosis, frequency of puncture, small kidneys and bleeding diathesis, although some have not been consistent in the literature [20, 21]. We reviewed clinical and laboratory factors previously related to complications with the aim of defining potential risk factors and possible cutoff points that may have contributed to the development of major complications in patients who underwent real-time ultrasound-guided PRB with an automated biopsy device.

\section{Material and methods}

The present series included all patients who underwent a PRB between January 1998 and April 2008 at the Instituto Nacional de Ciencias Médicas y Nutrición Salvador Zubirán in Mexico City. Biopsies were performed by trained nephrology fellows using an automated PRB device with a 16-gauge needle (Bard Corp. NJ, USA). In addition, the fellow was guided by real-time ultrasonography by an experienced radiologist and supervised by a nephrologist from the institute.

Ideally, every patient should have normal blood pressure ( $\leq 130 / 90 \mathrm{mmHg}$ ), a negative urine culture, and normal coagulation tests (prothrombin time, and plasma thromboplastin time in all patients and bleeding time in cases with BUN over $50 \mathrm{mg} / \mathrm{dl}$ ) prior to the PRB. After the procedure, patients remained hospitalized for $24 \mathrm{~h}$.

The efficiency of the procedure was determined based on the number of glomeruli obtained and whether the nephropathologist considered the material to be sufficient to establish a diagnosis.

Safety was evaluated on the basis of the presence or absence of major or minor complications. We considered major complications as those that required a blood transfusion, surgical intervention and extended hospitalization, whereas a minor complication was defined as a complication that did not require transfusion or surgical intervention (usually minor hematomas or transient hematuria that resolved spontaneously and did not prolong hospitalization over the $24-\mathrm{h}$ period after the procedure).

Patients who presented complications were identified and classified based on whether the complications were major or minor. Patients identified as having major complications were compared with the rest of the population (those with minor complications and those who did not present any complications) to identify potential risk factors for major complications. We analyzed the following independent variables: age, gender, blood pressure at the time of the biopsy, indication for PRB, concurrent medical conditions at the time of the biopsy, number of shots or passes during the procedure, histopathological diagnosis, and body mass index. In addition, we examined the following pre-biopsy laboratory variables: prothrombin time, partial thromboplastin time, hemoglobin, hematocrit, platelet count, serum creatinine, blood urea nitrogen (BUN), and serum and urinary albumin concentrations.

\section{Statistical analysis}

Results are expressed as frequencies (percentage) and mean \pm SD (range) for categorical and continuous variables, respectively. For continuous variables, such as systolic and diastolic blood pressure, hemoglobin, prothrombin time, thromboplastin time, platelets, serum creatinine and BUN, the most significant cut-off points were determined through receiver operating characteristic (ROC) curve analysis. Comparisons between groups were performed by means of $\chi^{2}$ tests for categorical data, and a logistic multivariate regression model was used to evaluate risk factors. The following variables were included in the logistic regression model: age at time of biopsy (continuous), gender (binary: female or male), comorbidities (diabetes mellitus: $1=$ yes or $2=$ no; systemic lupus erythematosus: $1=$ yes or $2=$ no; liver disease: 1 = yes or 2 = no; dyslipidemia: 1 = yes or 2 = no; and overweight/obesity: $1=$ yes or 2 = no); systolic blood pressure $\geq 140 \mathrm{mmHg}$ 
( 1 = yes or $2=$ no), diastolic blood pressure $\geq 90 \mathrm{mmHg}(1=$ yes or $2=$ no), hemoglobin $\leq 10 \mathrm{~g} / \mathrm{dl}(1=$ yes or $2=\mathrm{no})$, prothrombin time $\geq 12 \mathrm{~s}(1=$ yes or $2=$ no), thromboplastin time $\geq 35 \mathrm{~s}\left(1=\right.$ yes or $2=$ no), platelets $\leq 120 \times 10^{3} / \mu \mathrm{l}$ $(1=$ yes or $2=\mathrm{no})$, serum creatinine $\geq 1.5 \mathrm{mg} / \mathrm{dl}$ ( $1=$ yes or $2=$ no), blood urea nitrogen $\geq 60 \mathrm{mg} / \mathrm{dl}$ ( $1=$ yes or $2=$ no), number of passes $\geq 3$ ( $1=$ yes or $2=$ no). All $p$ values were two-tailed, and the statistical significance level was defined as $p$-value $<0.05$.

\section{Results}

During the study period, 646 native kidney PRBs were performed using an automated biopsy device and real-time ultrasound guidance. Out of the 646 PRBs, 623 (96.4\%) were analyzed and 23 were excluded due to incomplete information in the patient's chart. Demographic characteristics and laboratory findings are shown in Table I. The mean age of the patients was $34.4 \pm 14.2$ years, and $70.5 \%$ of the patients were female. The most frequent comorbidity was systemic lupus erythematosus (45.7\%). The main clinical indications that led to a PRB were nephrotic syndrome (382 cases, 61.3\%), hematuria-proteinuria (80 cases, 12.8\%), and nephritic syndrome (56 cases, 9\%) (Figure 1).

In the present study, lupus nephritis was the main histological finding (279 cases, 44.7\%) followed by focal segmental glomerulosclerosis (FSGS) in 102 cases (16.4\%) and 58 cases (9.3\%) of membranous nephropathy (Figure 2). The incidences of primary glomerulopathies were as follows: focal segmental glomerulosclerosis $16.4 \%$, idiopathic membranous nephropathy $9.3 \%$, IgA nephropathy $3.3 \%$, minimal change disease $4.9 \%$, and crescentic glomerulopathy $1.9 \%$. There were 32 patients with other histological findings: 6 cases of HenochSchönlein purpura, 6 cases of membranoproliferative glomerulonephritis, 3 cases of adjuvant disease, 3 cases of normal kidney, 2 cases of Alport's syndrome, 2 cases of Fabry's disease,

Table I. Demographic and laboratory characteristics of our patient population

\begin{tabular}{|c|c|c|c|c|}
\hline Variables & $\begin{array}{c}\text { Total } \\
(n=623)\end{array}$ & $\begin{array}{l}\text { With major } \\
\text { complications } \\
(n=14)\end{array}$ & $\begin{array}{l}\text { Without major } \\
\text { complications } \\
\quad(n=609)\end{array}$ & Value of $p$ \\
\hline Female (\%) & $439(70.5)$ & $14(100)$ & $425(69.8)$ & 0.04 \\
\hline Age [years], mean \pm SD & $34.4 \pm 14.2$ & $32.7 \pm 12.2$ & $34.4 \pm 14.2$ & NS \\
\hline \multicolumn{5}{|l|}{ Comorbidities (\%) } \\
\hline Systemic lupus erythematosus & $285(45.7)$ & $12(85.7)$ & $273(44.8)$ & 0.001 \\
\hline Overweight/obesity (IMC > 27 kg/m²) & $190(30.5)$ & $2(14.3)$ & $188(30.9)$ & NS \\
\hline Arterial hypertension & $168(27.1)$ & $4(28.6)$ & $164(27)$ & NS \\
\hline Dyslipidemia & $83(13.4)$ & $1(7.1)$ & $82(13.5)$ & NS \\
\hline Diabetes mellitus & $41(6.6)$ & $0(0)$ & $41(6.8)$ & NS \\
\hline Liver disease & $8(1.3)$ & $0(0)$ & $8(1.3)$ & NS \\
\hline \multicolumn{5}{|l|}{ Pre-biopsy laboratories (mean \pm SD) } \\
\hline $\begin{array}{l}\text { Hemoglobin }[\mathrm{g} / \mathrm{dl}] \\
\text { (max-min) }\end{array}$ & $\begin{array}{l}12.2 \pm 2.5 \\
(6.3-19.1)\end{array}$ & $\begin{array}{c}10.1 \pm 2.1 \\
(7.6-15)\end{array}$ & $\begin{array}{l}12.2 \pm 2.4 \\
(6.3-19.1)\end{array}$ & $<0.001$ \\
\hline $\begin{array}{l}\text { Platelets }\left(\times 10^{3} / \mu \mathrm{l}\right) \\
(\max -\mathrm{min})\end{array}$ & $\begin{array}{l}281 \pm 112 \\
(51-957)\end{array}$ & $\begin{array}{c}207.9 \pm 106 \\
(92-424)\end{array}$ & $\begin{array}{c}283 \pm 112.4 \\
(51-957)\end{array}$ & 0.009 \\
\hline $\begin{array}{l}\text { Prothrombin time }[\mathrm{s}] \\
\text { (max-min) }\end{array}$ & $\begin{array}{c}10.1 \pm 1.5 \\
(4-15.9)\end{array}$ & $\begin{array}{c}10.1 \pm 1.9 \\
(4-15.9)\end{array}$ & $\begin{array}{c}10.2 \pm 2.9 \\
(9-12.8)\end{array}$ & NS \\
\hline $\begin{array}{l}\text { Thromboplastin time [s] } \\
\text { (max-min) }\end{array}$ & $\begin{array}{c}29.4 \pm 4.5 \\
(20-46)\end{array}$ & $\begin{array}{c}30.3 \pm 6.1 \\
(22-39)\end{array}$ & $\begin{array}{c}29.8 \pm 7.5 \\
(20-46)\end{array}$ & NS \\
\hline $\begin{array}{l}\text { Serum creatinine }[\mathrm{mg} / \mathrm{dl}] \\
\text { (max-min) }\end{array}$ & $\begin{array}{l}1.7 \pm 1.5 \\
(0.1-13)\end{array}$ & $\begin{array}{l}2.1 \pm 0.86 \\
(0.9-3.2)\end{array}$ & $\begin{array}{l}1.7 \pm 1.5 \\
(0.1-13)\end{array}$ & 0.018 \\
\hline $\begin{array}{l}\text { Blood urea nitrogen }[\mathrm{mg} / \mathrm{dl}] \\
\text { (max-min) }\end{array}$ & $\begin{array}{c}29.4 \pm 22.3 \\
(3.1-137)\end{array}$ & $\begin{array}{c}56.5 \pm 28.2 \\
(16-98.4)\end{array}$ & $\begin{array}{c}28.7 \pm 21.7 \\
(3.1-137)\end{array}$ & $<0.001$ \\
\hline $\begin{array}{l}\text { Serum albumin [g/dl] } \\
\text { (max-min) }\end{array}$ & $\begin{array}{l}2.4 \pm 0.91 \\
(0.6-4.8)\end{array}$ & $\begin{array}{c}1.87 \pm 0.59 \\
(1-2)\end{array}$ & $\begin{array}{c}2.47 \pm 0.90 \\
(0.6-4.2)\end{array}$ & 0.031 \\
\hline $\begin{array}{l}\text { Albuminuria [g/day] } \\
\text { (max-min) }\end{array}$ & $\begin{array}{l}6.0 \pm 5.1 \\
(0.1-39)\end{array}$ & $\begin{array}{l}4.9 \pm 3.03 \\
(0.21-10.8)\end{array}$ & $\begin{array}{l}6.1 \pm 5.2 \\
(0.1-39)\end{array}$ & NS \\
\hline
\end{tabular}




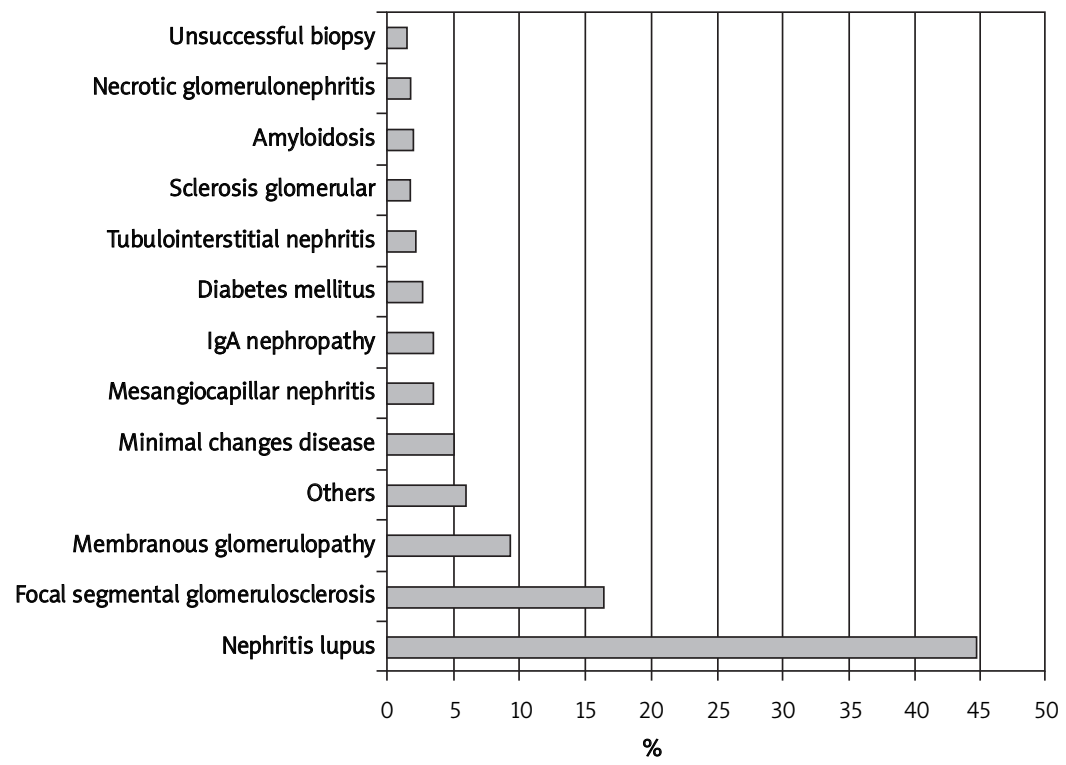

Figure 1. The most frequent biopsy indications of our series (1998 to 2008)

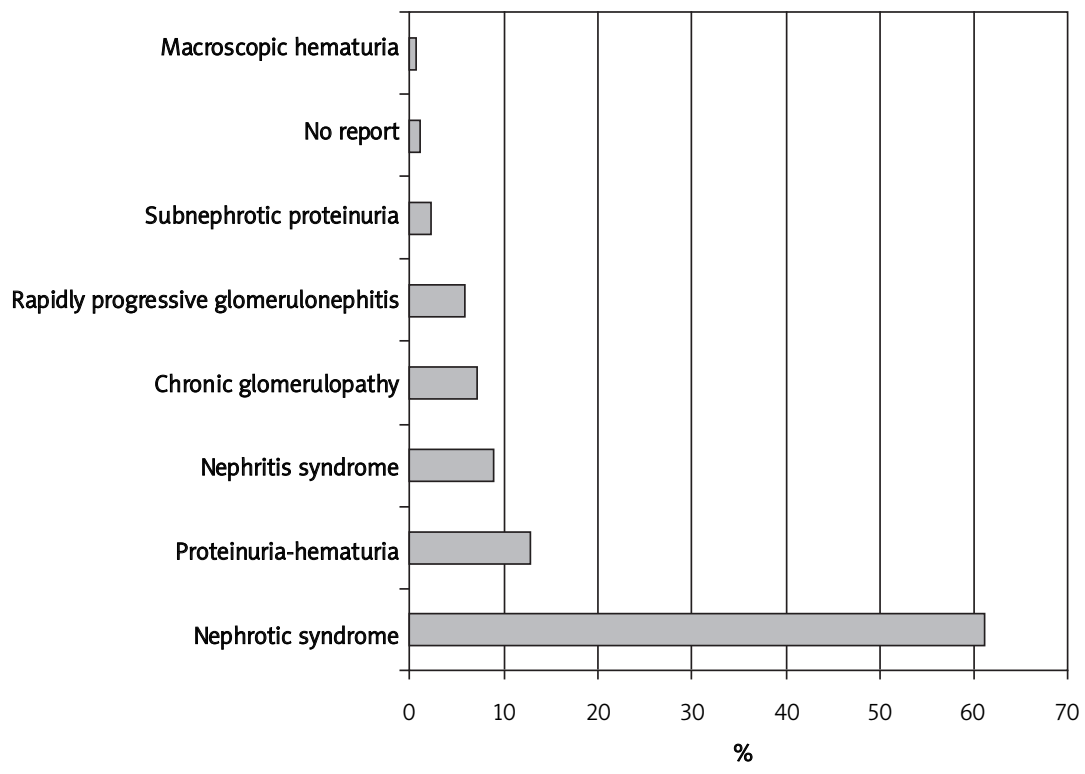

Figure 2. The most frequent histological findings of our series (1998 to 2008)

2 cases of dense deposit disease and 1 case of each of the following diagnoses: plasma cell dyscrasia, renal infiltration by leukemia, thin membrane disease, glomerulopathy linked to POEMS syndrome (polyneuropathy, organomegaly, endocrinopathy, monoclonal gammopathy, and skin changes), lecithin-cholesterol acyltransferase (LCAT) deficiency, idiopathic nodular glomerulosclerosis, nephropathy linked to the human immunodeficiency virus and immunotactoid glomerulonephritis.

Although 285 patients had a clinical diagnosis of lupus, we only confirmed the histological diagnosis of lupus in 279 patients and the rest had some other histological findings described above. According to the ISN/RPS lupus nephritis histological classification, the varieties of lupus nephritis among the 279 patients were diffuse proliferative glomerulonephritis type IV (46\%, 129/279), focal proliferative glomerulonephritis type III (17\%, 48/279), membranous glomerulonephritis type $\mathrm{V}(14 \%, 38 / 279)$, and the mesangial variety type II $(5 \%, 14 / 279)$. In addition, combined histopathological forms were diagnosed: $7 \%(19 / 279)$ of cases had features of types III and V, and 6\% (16/279) presented features of types IV and V. 


\section{Safety evaluation}

The present study observed a total of 110 complications (17.6\%). Among these complications, 96 (15.24\%) were minor and 14 (2.24\%) were major. The most frequent minor complication was the presence of an ultrasound-detected hematoma, which occurred in 87 cases (13.9\%), followed by transient hematuria in 8 cases $(1.2 \%)$, which did not require transfusion. A major hematoma requiring blood transfusion ( $n=9,1.4 \%$ of the total population) was the most common major complication. In addition, we observed hematuria requiring transfusion in 2 cases ( $0.3 \%$ of the total population). Moreover, selective embolization secondary to hematoma, nephrectomy and intestinal perforation were each observed in one case (each complication accounted for $0.16 \%$ of the total population).

\section{Efficiency evaluation}

In our study, of 623 biopsies analyzed, there were 608 biopsies (97.5\%) with an adequate sample (representative) to establish the histopathological diagnosis. Of these, 468 biopsies had more than 10 glomeruli $(76.9 \%), 110$ biopsies had 6 to 10 glomeruli (18.1\%), and 30 biopsies had 1 to 5 glomeruli (5\%). There were five procedures with inadequate or insufficient histological material to establish a diagnosis, and ten procedures were considered unsuccessful because no renal tissue was obtained.

\section{Risk factors for major complications}

We investigated the risk factors associated with the development of major complications in procedures using the automated PRB device by comparing patients who developed major complications $(n=14)$ with patients who did not present major complications $(n=609)$. As a result of the univariate analysis, the following variables were found to be significantly associated with major complications: female gender, systemic lupus erythematosus, diastolic blood pressure $\geq 90 \mathrm{mmHg}$, hemoglobin $\leq 10 \mathrm{~g} / \mathrm{dl}$, prothrombin time $\geq 12 \mathrm{~s}$, number of platelets $\leq 120 \times 10^{3} / \mu \mathrm{l}$, serum creatinine $\geq 1.5 \mathrm{mg} / \mathrm{dl}$, and $\mathrm{BUN} \geq 60 \mathrm{mg} / \mathrm{dl}$ (Table II). However, in the logistic multivariable regression analysis, only the following variables were found to have an independent effect: diastolic blood pressure $\geq 90 \mathrm{mmHg}$, RR $7.6(95 \% \mathrm{Cl} 1.35-43.12$, $p=0.021) ;$ platelets $\leq 120 \times 10^{3} / \mu \mathrm{l}, \mathrm{RR} 7.0(95 \% \mathrm{Cl}$ 1.92-26.24, $p=0.003)$; and serum $\mathrm{BUN} \geq 60 \mathrm{mg} / \mathrm{dl}$, RR $9.27(95 \% \mathrm{Cl} 2.80-30.7, p<0.01)$.

\section{Discussion}

Our data show the safety/efficacy profile of realtime ultrasound for percutaneous renal biopsies (PRBs) by analyzing 623 consecutive procedures

Table II. Univariate analysis of risk factors for major complications

\begin{tabular}{|lccccc|}
\hline Variable & $\begin{array}{c}\text { With major } \\
\text { complications } \\
(n=14)\end{array}$ & $\begin{array}{c}\text { Without major } \\
\text { complications } \\
(n=609)\end{array}$ & RR & 95\% Cl & Value of $p$ \\
\hline Female (\%) & $14(100)$ & $425(69.8)$ & 6.6 & $0.9-49.8$ & 0.03 \\
\hline Arterial hypertension (\%) & $4(28.6)$ & $164(27)$ & 1.2 & $0.4-3.6$ & 1.00 \\
\hline Diabetes mellitus (\%) & $0(0)$ & $41(6.8)$ & 0.9 & $0.9-1.0$ & 0.62 \\
\hline Systemic lupus erythematosus (\%) & $12(85.7)$ & $298(49.1)$ & 4.8 & $1.38-17.1$ & 0.007 \\
\hline Dyslipidemia (\%) & $1(7.1)$ & $82(13.5)$ & 0.4 & $0.05-3.0$ & 0.72 \\
\hline Liver diseases (\%) & $0(0)$ & $8(1.3)$ & 0.9 & $0.9-1.0$ & 1.00 \\
\hline Overweight/obesity (\%) & $2(14.3)$ & $188(30.9)$ & 0.5 & $0.13-1.69$ & 0.30 \\
\hline Systolic blood pressure $\geq 140 \mathrm{mmHg}(\%)$ & $3(21.4)$ & $85(14.4)$ & 0.5 & $0.18-1.66$ & 0.29 \\
\hline Diastolic blood pressure $\geq 90 \mathrm{mmHg}(\%)$ & $2(14.3)$ & $11(1.9)$ & 5.2 & $1.9-13.9$ & 0.04 \\
\hline Hemoglobin $\leq 10 \mathrm{~g} / \mathrm{dl}(\%)$ & $8(57.1)$ & $131(21.8)$ & 4.9 & $1.88-12.5$ & 0.001 \\
\hline Prothrombin time $\geq 12 \mathrm{~s}(\%)$ & $5(41.7)$ & $65(11.9)$ & 4.7 & $1.5-14.4$ & 0.013 \\
\hline Thromboplastin time $\geq 35 \mathrm{~s}(\%)$ & $4(28.6)$ & $83(15.2)$ & 2.0 & $0.62-6.48$ & 0.27 \\
\hline Platelets $\leq 120 \times 103 / \mu \mathrm{l}(\%)$ & $4(28.6)$ & $21(3.5)$ & 12.1 & $3.8-37.5$ & $<0.01$ \\
\hline Serum creatinine $\geq 1.5 \mathrm{mg} / \mathrm{dl}(\%)$ & $10(7.4)$ & $225(37.2)$ & 4.1 & $1.4-11.7$ & 0.009 \\
\hline Blood urea nitrogen $\geq 60 \mathrm{mg} / \mathrm{dl}(\%)$ & $7(50)$ & $53(8.9)$ & 9.3 & $3.42-25.0$ & $<0.01$ \\
\hline Number of passes $\geq 3(\%)$ & $1(7.7)$ & $9(1.5)$ & 5.3 & $0.62-45.5$ & 0.199 \\
\hline
\end{tabular}

$¥$ Number of passes: number of times that the needle penetrates the kidney tissue 
performed from January 1998 to April 2008. In line with other previously published series, effectiveness was $97.6 \%$, with a $2.24 \%$ rate of major complications [21-23]. Our institute is a reference center for lupus erythematosus, which explains the high prevalence of lupus erythematosus diagnosis and a relatively young population, most of whom had nephrotic syndrome. In Table III, we compared the histopathological diagnoses of the present study with those of other large native kidney PRB series [24-29]. Our population displayed a low frequency of IgA nephropathy, which was not entirely surprising because patients in our institute with a history of occasional macroscopic hematuria, microscopic hematuria or, in some cases, additional low grade proteinuria are often observed and treated in the outpatient clinic. Indeed, these patients were only considered for PRB if the procedure was clearly justified, such as cases involving increasing proteinuria or serum creatinine [30].

In this series, the efficiency of the automated technique was similar to that of most other published series [12, 15], and the procedure was found to be relatively safe. Indeed, the frequency of major complications was only $2.24 \%$, which was similar to, or even lower than, the frequencies seen with other invasive procedures, for example subclavian catheter placement (1.03\%), diagnostic endoscopy (1.71\%), liver biopsy (2.8\%), and general anesthesia in patients with ASA I-II (0.59\%) [16]. Whittier and Korbet examined 750 patients and found that 48 patients developed major complications (6.4\%). Out of these patients, the majority required a blood transfusion, although there were two deaths directly related to PRB. In our series, 11 patients $(1.7 \%)$ required a blood transfusion, and there were no reported deaths. Nevertheless, 3 patients $(0.48 \%)$ required an invasive intervention as a result of the procedure, which was slightly less than the percentage reported by Whittier and Korbet [21]. In the present series, we observed one case of intestinal perforation $(0.16 \%)$, which was adequately managed with surgery, similar at reported by Rasheed et al. in a series of 104 pediatric patients who underwent PRB, who only reported one case of intestinal perforation (0.96\%) [31]. The frequency of nephrectomy linked to the PRB procedure has been variable between studies. For example, Manno et al. reported an incidence of post-biopsy nephrectomy of $0.26 \%$ [32], discreetly major compared with $0.16 \%$ in our series.

We compared the efficiency and safety of the current series (using real-time ultrasound guidance and an automated biopsy device) with a previous series of patients who underwent PRBs with a manual technique (1,005 biopsies) from January 1970 to March 1996 [16]. The comparison of the two techniques demonstrated a significant increase in efficacy with the current technique (Table IV). We believe that the improvement in the effectiveness using real time ultrasound was associated with the certainty of obtaining renal tissue due to the direct vision of the kidney at the time of puncture, while in the manual technique such certainty is lacking and up to $25 \%$ of the biopsies do not have enough material for diagnosis [16]. On the other hand, within the concept of efficiency some authors consider representative biopsy, when between 8 and 10 glomeruli per sample are obtained; however, others consider representative biopsy those with which it is possible to make a histological diagnosis [33]. There is no general consensus yet on the number of glomeruli needed to make the diagnosis, because this number varies from one for diffuse nephropathies to 25 for focal nephropathies $[34,35]$. However, data analysis using the number of glomeruli as a definition of efficiency may not be appropriate because, as commented previously, in many cases the diagnosis can be made with less than 8 glomeruli, provided histological lesions are representative for a particular disease [33, 34].

Table III. Comparison of the main histological findings among different series of published studies

\begin{tabular}{|c|c|c|c|c|c|c|c|c|c|c|}
\hline Author (reference) & Center & $N$ & $\mathrm{PGN}^{\dagger}$ & FSGS $^{\ddagger}$ & $\operatorname{MesG}^{\pi}$ & $\operatorname{IgAN} ¥$ & MPG" & $\mathrm{MG}^{\dagger+}$ & GS\# & MCD \\
\hline Dragovic et al. [24] & New York, USA & 299 & 57.6 & 37.8 & - & 27.3 & - & 16.6 & - & 9.1 \\
\hline Malafronte et al. [25] & Sao Paolo, Brazil & 1,844 & 54.2 & 29.7 & 3.8 & 17.8 & 7 & 20.7 & 4.1 & 9.1 \\
\hline Covic et al. [26] & Bucharest, Romania & 635 & 66.2 & 11.5 & 28.9 & - & 29.4 & 11.2 & 7.9 & 8.5 \\
\hline Pacini et al. [27] & Pisa, Italy & 3,269 & 66 & 19.8 & 45.7 & - & - & 23 & - & 5.3 \\
\hline Chang et al. [28] & Seoul, Korea & 1,818 & 85.2 & 5.6 & - & 28.3 & 4 & 12.3 & - & 15.5 \\
\hline Kazi et al. [29] & Karachi, Pakistan & 316 & - & 39.8 & - & 2.5 & 4.1 & 26.5 & - & 14.8 \\
\hline $\begin{array}{l}\text { Torres et al. } \\
\text { (current study) }\end{array}$ & Mexico City, Mexico & 623 & 39.3 & 16.4 & 3.5 & 3.3 & - & 9.3 & 1.9 & 4.9 \\
\hline
\end{tabular}

Results are presented in percentages. ${ }^{\top} P G N$ - primary glomerulonephropathies, $\ddagger F S G S$ - focal segmental glomerulosclerosis, $\pi$ Mes $G$ - mesangial glomerulonephritis (not IgA), ${ }^{\sharp} \operatorname{gAN}$ - IgA nephropathy, "MPG - mesangioproliferative, ${ }^{+\dagger}$ membranous glomerulopathy, ${ }^{\ddagger \ddagger} G S-$ glomerular sclerosis, $¥ M C D$ - minimal change disease 
Table IV. Comparison of the efficacy and safety of percutaneous renal biopsy techniques (manual versus automated)

\begin{tabular}{|c|c|c|c|c|c|c|c|}
\hline Parameter & $\begin{array}{c}\text { Michaca et al., } \\
\text { México } \\
\text { (manual) } \\
(n=1,005)\end{array}$ & $\begin{array}{l}\text { Torres et al., } \\
\text { México } \\
\text { (automated) } \\
(n=623)\end{array}$ & $\begin{array}{l}\text { Toledo et al., } \\
\text { Spain } \\
\text { (automated) } \\
(n=797)\end{array}$ & $\begin{array}{l}\text { Castro et al., } \\
\text { Portugal } \\
\text { (automated) } \\
(n=91)\end{array}$ & $\begin{array}{c}\text { Donovan et al., } \\
\text { England } \\
\text { (automated) } \\
(n=192)\end{array}$ & $\begin{array}{l}\text { Eiro et al., } \\
\text { Japan } \\
\text { (automated) } \\
(n=394)\end{array}$ & $\begin{array}{l}\text { Hergesell et al., } \\
\text { Germany } \\
\text { (automated) } \\
(n=1090)\end{array}$ \\
\hline Efficacy [\%] & 88.7 & 97.6 & - & 92.3 & 97.8 & 98.5 & 98.8 \\
\hline \multicolumn{8}{|l|}{ Safety [\%] } \\
\hline $\begin{array}{l}\text { Minor } \\
\text { complications }\end{array}$ & 8.65 & 15.4 & 13.2 & 9.8 & - & 58.6 & 7.5 \\
\hline $\begin{array}{l}\text { Major } \\
\text { complications }\end{array}$ & 2.48 & 2.24 & 0.75 & 4.3 & 0 & 0 & 0.3 \\
\hline
\end{tabular}

Surprisingly, we also observed a significant increase in the incidence of minor complications with the current automated and ultrasound-guided technique. We think that this observation was likely caused by the use of ultrasound monitoring after the procedure in all patients of the present series because the patients of the previous series were not subjected to ultrasound monitoring, and only those who had a clinically relevant event were studied. Generally our safety results were not different from other comparable large series [35-39], except for our lower rate of minor complications compared with Eiro et al. [36] and a higher frequency of major complications compared with studies by Donovan et al. and Hergesell et al. [37, 38]. Moreover, within the major complications, there was no statistically significant difference when comparing the two groups in our population.

The analysis of risk factors demonstrated a statistically significant risk of major complications with the presence of high diastolic blood pressure, a low platelet count, and a high serum BUN. A diastolic blood pressure of $\geq 90 \mathrm{mmHg}$ increased the risk of major complications similarly to results described more than 10 years ago by Diaz-Buxo and Donadio [23]. In the same way, Eiro et al. showed that hypertension (systolic blood pressure $>140$ $\mathrm{mmHg}$ or diastolic blood pressure and $>90 \mathrm{mmHg}$ ) was an independent risk factor for post-biopsy bleeding [36]. In our case, the mechanism by which diastolic hypertension increases the development of major complications perhaps is related to the known association of diastolic hypertension and the development of microbleeds [40], which associated with renal puncture per se may increase the risk of developing major bleeding [32, 33, 41].

Our study showed that patients with a platelet count of $\leq 120 \times 10^{3} / \mu$ l had an increased risk of complications. In addition, a platelet count of less than 70,000 $\mathrm{U} / \mathrm{dl}$ has previously been shown to be associated with increased bleeding complications in hepatic biopsies [21]. A value (cut-off point) for a safe platelet count in PRB, however, has not been established. Because our PRB protocol did not include the routine evaluation of bleeding time, it was not possible to assess this variable as a potential risk factor. Furthermore, the univariate analysis showed a statistical link to complications in patients with prothrombin time (PT) $\geq 12 \mathrm{~s}$, but this association was not sustained in the multivariate analysis.

In the present study, we observed a significant increase in the number of complications in patients with BUN levels $\geq 60 \mathrm{mg} / \mathrm{dl}$. This finding could be related to the role of uremia in platelet dysfunction. An in vitro study showed that an increase in urea nitrogen altered the platelet aggregation process [42], and clinical studies have suggested that there is an increased risk of developing a hemorrhagic complication after PRB in patients with uremic syndrome [42, 43]. Although other studies have demonstrated an association between serum creatinine levels and complications [18, 44], our study was unable to prove this association. In addition, we were unable to confirm a link between the number of shots and passes with development of major complications.

Currently, technical advances have made PRB a safe outpatient procedure and have been used to diminish costs [22, 45]. In relation to the time of hospitalization, some authors recommend that patients be hospitalized overnight $[38,46]$. In our series, all of the complications presented within the first $6 \mathrm{~h}$ of observation, and another study showed that complications were evident within the first $3 \mathrm{~h}$ [47]. We believe that these findings support the concept that PRBs could safely be performed in an outpatient setting $[47,48]$.

On the other hand, an important factor to consider in assessing the invasive procedures is the skills and experience of the physician performing the procedure. As described in the methodology, in our hospital most biopsies are made by residents under the supervision of a nephrologist; therefore, it is possible that there is a potential learning curve effect associated with the safety and efficacy of the procedure. However, due to the retrospective nature of our study, we cannot know with certainty that 
information, which is a weakness of our work and we will try to study it in a future cohort.

In conclusion, use of the current PRB technique in our study resulted in similar levels of efficacy and safety as previous studies. The benefits of this new technique should be reported so that many healthcare centers in developing countries could consider using an automated biopsy device with real-time ultrasound. We revealed a number of independent risk factors for the development of major complications - diastolic blood pressure $\geq 90$ $\mathrm{mmHg}$, platelets $\leq 120 \times 10^{3} / \mu \mathrm{l}$ and $\mathrm{BUN} \geq 60 \mathrm{mg} / \mathrm{dl}$ - that must be taken into account to reduce the frequency of major complications.

\section{References}

1. Schwartz MM, Korbert SM, Lewis EJ. The value of the renal biopsy. In: Contemporary issues in nephrology. Narins RG, Stein JN (eds). New York, Churchill Livingstone 1992; 269-304.

2. Ball RP. Needle (aspiration) biopsy. Tenn State Med Ass J 1934; 27: 203

3. Iversen P, Brun C. Aspiration biopsy of the kidney. Am J Med 1951; 11: 324-30.

4. Kark RM, Muehrcke RC, Pirani CL. Biopsy of the kidney in the in the prone position. Lancet 1954; 1047-9.

5. Muehrcke RC, Kark RM, Pirani CL. Technique of percutaneous renal biopsy in the prone position. J Urol 1955; 74: 267-77.

6. Kark RM, Muehrcke RC, Pollak VE, et al. An analysis of 500 percutaneous renal biopsies. Arch Intern Med 1958; 101: 439-51.

7. Donnelly S, Goodyer P, Mauer M; RASS Investigators. Comparing the automated versus manual method of needle biopsy for renal histology Artefacts. Nephrol Dial Transplant 2008; 23: 2098-100.

8. Doyle AJ, Gregory MC, Terreros DA. Percutaneous native renal biopsy: comparison of a $1.2 \mathrm{~mm}$ spring-loaded system with a traditional $2 \mathrm{~mm}$ hand-driven system. Am J Kidney Dis 1994; 23: 498-503.

9. Dohun K, Heungsoo K, Gyutae S, et al. A randomized, prospective, comparative study of manual and automated renal biopsies. Am J Kidney Dis 1998; 32: 426-31.

10. Nass K, O`Neill WC. Bedside renal biopsy: ultrasound guidance by the nephrologist. Am J Kidney Dis 1999; 34: 955-9.

11. Birnholz JC, Kasinath BS, Corwin HL. An improved technique for ultrasound guided percutaneous renal biopsy. Kidney Int 1985; 27: 80-2.

12. Tang S, Li JH, Lui S. Free-hand, ultrasound-guided percutaneous renal biopsy: experience from a single operator. Europ J Radiol 2002; 4: 65-9.

13. Ori Y, Neuman $H$, Chagnac A, et al. Using the automated biopsy gun with real-time ultra-sound for native renal biopsy. Isr Med Assoc J 2002; 4: 698-701.

14. Korbert SM. Percutaneous renal biopsy. Semin Nephrol 2002; 22: 254-67.

15. Kim D, Kim H, Shin G, et al. A randomized, prospective, comparative study of manual and automated renal biopsy. Am J Kidney Dis 1998; 32: 426-31.

16. Burstein DM, Korbert SM, Schwartz MM. The use of the automatic core biopsy system in percutaneous renal biopsy: a comparative study. Am J Kidney Dis 1993; 22: 545-52.
17. Feneberg R, Schaefer F, Zieger B, et al. Percutaneous renal biopsy in children: a 27-year experience. Nephron 1998; 79: 438-46.

18. Health and Public Policy Committee, American College of Physicians: Clinical Competence in Percutaneous Renal Biopsy. Ann Intern Med 1988; 108: 301-3.

19. Salama AD, Renal biopsy. Medicine 2007; 35: 383-5.

20. Whittier WL, Korbet SM. Renal biopsy: update. Curr Opin Nephrol Hypertens 2004; 13: 661-5.

21. Khajehdehi P, Junaid SM, Salinas-Madrigal L, et al. Percutaneous renal biopsy in the 1990's: safety, value and implications for early hospital discharge. Am J Kidney Dis 1999; 34: 92-7.

22. Diaz-Buxo JA, Donadio JV. Complications of percutaneous renal biopsy: an analysis of 1, 000 consecutive biopsies. Clin Nephrol 1975; 4: 223-7.

23. Dragovic D, Rosenstock JL, Wahl SJ, Panagopoulos G, DeVita MV, Michelis MF. Increasing incidence of focal segmental glomerulosclerosis and an examination of demographic patterns. Clin Nephrol 2005; 63: 1-7.

24. Malafronte P, Mastroianni-Kirsztajn G, Betônico GN, et al. Paulista Registry of glomerulonephritis: 5-year data report. Nephrol Dial Transplant 2006; 21: 3098-105.

25. Covic A, Schiller A, Volovat C, et al. Epidemiology of renal disease in Romania: a 10 year review of two regional renal biopsy databases. Nephrol Dial Transplant 2006; 21: 419-24.

26. Panichi V, Pasquariello A, Innocenti $M$, et al. The Pisa experience of renal biopsies, 1977-2005. J Nephrol 2007; 20: 329-35.

27. Chang JH, Kim DK, Kim HW, et al. Changing prevalence of glomerular diseases in Korean adults: a review of 20 years of experience. Nephrol Dial Transplant 2009; 24: 2406-10.

28. Kazi Jl, Mubarak M, Ahmed E, Akhter F, Naqvi SA, Rizvi SA. Spectrum of glomerulonephritides in adults with nephrotic syndrome in Pakistan. Clin Exp Nephrol 2009; 13: 38-43.

29. D'Amico G. The commonest glomerulonephritis in the world: IgA nephropathy. Q J Med 2001; 64: 709-27.

30. Rasheed SA, Mugeiren MA, Abdurrahman MB, Elidrissy AT. The outcomes of percutaneous renal biopsy in children: an analysis of 120 consecutive cases. Ped Nephrology 1990; 6: 600-3.

31. Manno C, Strippoli GF, Arnesano L, et al. Predictors of bleeding complications in percutaneous ultrasound-guided renal biopsy. Kidney Intern 2004; 66: 1570-7.

32. Madaio MP. Renal biopsy. Kidney Int 1990; 38: 529-43.

33. Cotwn'i HL, Schwartz MM, Lewis EJ. The importance of sample size in the interpretation of renal biopsy. Am J Nephrol 1988; 8: 85-9.

34. Michaca LG, Chew-Wong A, Sotelo L, Gamba G, CorreaRotter R. Biopsia renal percutánea: Análisis de 26 años, tasa de complicaciones y factores de riesgo. Revista de Investigación Clínica 52: 125-31.

35. Castro R, Roquete P, Silvestre F, Morgado T. Percutaneous kidney biopsy: eight years-experience. Acta Med Port 2004; 17: 20-6.

36. Eiro M, Katoh T, Watanabe T. Risk factors for bleeding complications in percutaneous renal biopsy. Clin Exp Nephrol 2005; 9: 40-5.

37. Donovan KL, Thomas DM, Wheeler DC, Macdougall IC, Williams JD. Experience with a new method for percutaneous renal biopsy. Nephrol Dial Transplant 1991; 6: 731-3.

38. Hergesell O, Felten H, Andrassy K, Kühn K, Ritz E. Safety of ultrasound-guided percutaneous renal biopsy- 
retrospective analysis of 1090 consecutive cases. Nephrol Dial Transplant 1998; 13: 975-7.

39. Toledo K, Pérez MJ, Espinosa M, et al. Complications associated with percutaneous renal biopsy in Spain, 50 years later. Nefrología 2010; 30: 539-43.

40. Whittier WI, Korbet SM. Timing of complications in percutaneus renal biopsy. J Am Soc Nephrol 2004; 15: 142-7.

41. Naganuma T, Takemoto Y, Yamasaki T, et al. Factors associated with silent cerebral microbleeds in hemodialysis patients. Clin Nephrol 2011; 75: 346-55.

42. Steiner RW, Coggins C, Carvalho ACA. Bleeding time in uremia: a useful test to assess clinical bleeding. Am J Hematol 1979; 7: 107-17.

43. Shidam GB, Siddiqi N, Beres JA, et al. Clinical risk factors associated with bleeding after native kidney biopsy. Nephrology 2005; 10: 305-10.

44. Parrish AE. Complications of percutaneous renal biopsy: a review of 37 years experience. Clin Nephrol 1992; 38: 135-41.

45. Fraiser I, Fairley K. Renal biopsy as an outpatient procedure. Am J Kidney Dis 1995; 25: 876-8.

46. Nelson CL, Mackinnon MW, Charlesworth JA. Importance of renal biopsy. Nephrology 2001; 6: 270-3.

47. Al-Hweish AK, Abdul-Rehaman IS. Outpatient percutaneous renal biopsy in adult patients. Saudi J Kidney Dis Transplant 2007; 18: 541-6.

48. Mahajan V, Suri D, Saxena A, Nada R. Should ultrasound guided percutaneous renal biopsy in children be done in a day care setting? Indian J Nephrol 2010; 20: 21-4. 